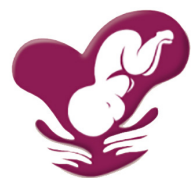

Published By: PERINASIA

The Indonesian Society of Perinatology

\section{The effect of Katuk leaf to breastfeeding mother: a literature review}

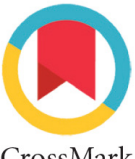

CrossMark

\author{
Alfonsus Zeus Suryawan ${ }^{1}$, Nicholas Renata Lazarosony ${ }^{2 *}$
}

'Faculty of Medicine, Universitas Kristen Maranatha, Bandung Indonesia ${ }^{2}$ Department of Obstetrics \& Gynecology, Faculty of Medicine, Universitas Udayana, Bali

*Corresponding to:

Nicholas Renata Lazarosony, Department of Obstetrics \& Gynecology, Faculty of Medicine, Universitas Udayana, Bali; nicholrenata@gmail.com

Received: 2021-02-10

Accepted: 2021-06-30

Published: 2021-07-16

\section{ABSTRACT}

Indonesians traditionally consume Katuk (Sauropus androgynus (L) Merr) leaf to treat various diseases, improve weight loss, and as vegetable dishes. Sauropus androgynus, also known as a medicinal plant with high antioxidant potential, is also traditionally utilized to increase breastmilk production during lactation. Lactation is a process of milk synthesis and secretion, in which Prolactin responsible for the synthesis of breastmilk. Recent studies have proven that Katuk leaf extract can increase the breastfeeding quality and prolactin level in breastfeeding women. This article provides a brief summary of evidence supporting the use of Katuk leaf to improve breastmilk production in breastfeeding mothers.

Keywords: Katuk leaf, Sauropus androgynus, Breastfeeding, Prolactin. Cite This Article: Suryawan, A.Z., Lazarosony, N.R. 2021. The effect of Katuk leaf to breastfeeding mother: a literature review. Indonesian Society Of Perinatology 2(2): 25-28. D0I: 10.51559/inajperinatol.v2i2.12

\section{INTRODUCTION}

Breastfeeding is a physiological process to provide optimal nutrition to babies. Breast milk is the best nutrition for babies because it contains all the nutrients, antibodies, hormones, and immune factors and antioxidants that babies need to grow and develop primarily during the first six months of life. Breastfeeding is the primary source of nutrition for babies to achieve normal growth, development and immunological protection. Unfortunately, not all babies can get adequate ASI. UNICEF in 2005 reported that there were 30,000 infant deaths in Indonesia and 10 million toddler deaths in the world every year, but this could be reduced partly simply by providing exclusive breastfeeding. The problem usually occurs in breastfeeding mothers is the lack of milk production, affecting infants' exclusive breastfeeding period. Lack of milk production is caused by various nutritional and non-nutritional factors, including hormonal problems, parity, pregnancy, age and psychological factors. The usual problem arises from the primary hormone's improper physiological release, the Prolactin and oxytocin. ${ }^{1}$ This is where Katuk leaf roles come into play. Katuk (Sauropus androgynus (L) Merr) is a shrub that belongs to the Euphorbiaceae family. Katuk leaf itself is a galactagogue that is believed by the traditional public to increase breastmilk production. Recent studies found that Katuk leaf contains several compounds that useful for the synthesis and production of breastmilk. Here we will provide a short review of the evidence support Katuk leaf's use to improve breastmilk production in breastfeeding mothers.

\section{KATUK LEAF}

Sauropus androgynus (SA), likewise called star gooseberry, is a tropical bush from the Euphorbiaceae family (Figure 1). The Indian, Indonesian, and Thai names of SA are Chhakrmani, Katuk, and Phak Wan Ban, respectively. ${ }^{2}$ Katuk leaves contain high phenolic content and antioxidant activities. ${ }^{3}$ It is rich in carotenoids, flavonoids, and various other phytochemicals. These phytochemicals can reduce oxidative stress. Katuk leaf has moderately high macronutrient and vitamin. The katuk plant, including the leaf, has high vitamin $\mathrm{C}, \mathrm{B} 1$ and $\mathrm{B} 2$. The measures of this vitamin $B$ are considered higher than numerous other leafy vegetables. ${ }^{5}$ Another significant part of
Katuk leaf other than its high nutrient and supplement is that it contains a high level of cancer prevention agents, which comes in flavonoid and alkaloid. Katuk additionally acts as a galactagogue. Galactagogues are the substance that induces, maintain and increase milk production. ${ }^{1}$

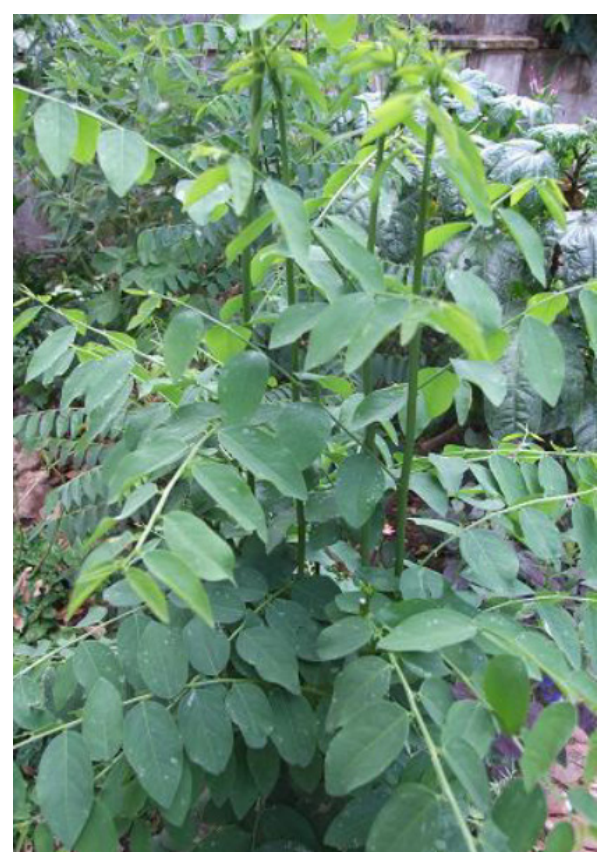

Figure 1. Katuf Leaf (Sauropus androgynus L. Merr). ${ }^{4}$ 


\section{PHYSIOLOGY OF BREASTFEEDING}

Breastfeeding is a physiological process to provide optimal nutrition to babies. Several hormones play a role in breastfeeding, but two main chemicals influence breastfeeding: Prolactin and Oxytocin hormone. Various other chemicals, for example estrogen, are also influenced lactation indirectly. When the infant starts suckling the breast, a tactile stimulus pass from the areola to the central nervous system and the anterior pituitary responded by secreting the Prolactin, and the posterior pituitary release oxytocin. ${ }^{6}$

Prolactin is essential for the alveoli cells to be able to secrete milk. The degree of Prolactin in the blood increases markedly during pregnancy and induces the development and growth of the mammary tissue in anticipation of breast milk production (Figure 2). Instead of synthesis and secrete milk soon afterward, the progesterone and estrogen block these particular Prolactin's activity up until delivery. Both hormones fall rapidly after delivery. Prolactin, which is no longer blocked, induced milk secretion. ${ }^{7}$

At the point when an infant suckles, the degree of Prolactin in the blood increases, and stimulates the synthesis of breastmilk by the alveoli cells. The prolactin level spike around 30 minutes after the breastfed start, so its most significant impact is to make milk for the following feed. ${ }^{8}$ During the initial few weeks, the more breastfed and areola stimulation received, the more Prolactin is secreted, and the more milk is delivered. This impact is especially significant in the early establishment of breastfeeding.

Oxytocin, the other hormone counterpart, makes the myoepithelial cells around the alveoli contract. This makes the milk, which has gathered in the alveoli, stream along and fill the ducts. ${ }^{10}$ The oxytocin reflex is also known as the "letdown reflex" or the "milk discharge reflex". The mechanism illustrated in Figure 3. Oxytocin is secreted more rapidly than Prolactin. It makes the milk that is now in the breast flow for the current feed, and encourages the infant to get the milk without any problem. Oxytocin begins working when a mother expects a feed, just as when the child suckles the breast. The reflex gets molded to the mother's sensations and sentiments, such as contacting, smelling or seeing her infant, hearing her infant cry, or just pondering her baby. Conversely, if the mother is in pain or emotionally upset, the oxytocin reflex may get repressed, and her milk may not flow. Oxytocin likewise makes a mother's uterus contract after delivery and assists in stopping the bleeding. However, severe uterine contraction can cause pain in the initial breastfeeding period.

\section{KATUK LEAF AND BREASTFEEDING}

Katuk is also believed to increase breastmilk production. This is supported by the research results that show 12 days of katuk supplementation to Wistar rat can increase prolactin gene expression by 14.6 times compared to the control group. ${ }^{12}$ The increment of gene expression by katuk leaves occurred because of an alkaloid within the leaf itself, the Papaverine. Papaverine has a dilatating effect on smooth muscle and dilates blood vessels, increasing the oxygenation of mammary cells and increasing the circulating hormones Oxytocin and Prolactin. The phytosterols in katuk leaves have a hormonal effect from chemical sterols, which induces the prolactin hormone receptor's expression. A study explains that phytoestrogens are compounds that can increase the hormone prolactin and breastmilk production. Phytoestrogens have biological action similar to estrogen

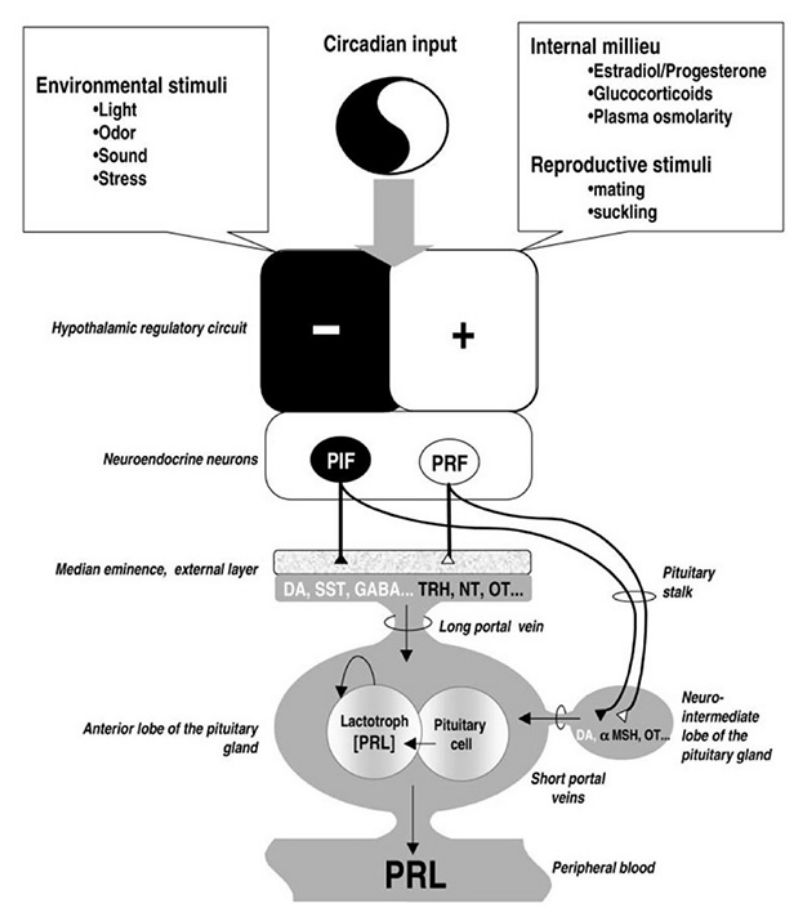

Figure 2. Physiologic Effect of Prolactin. ${ }^{9}$

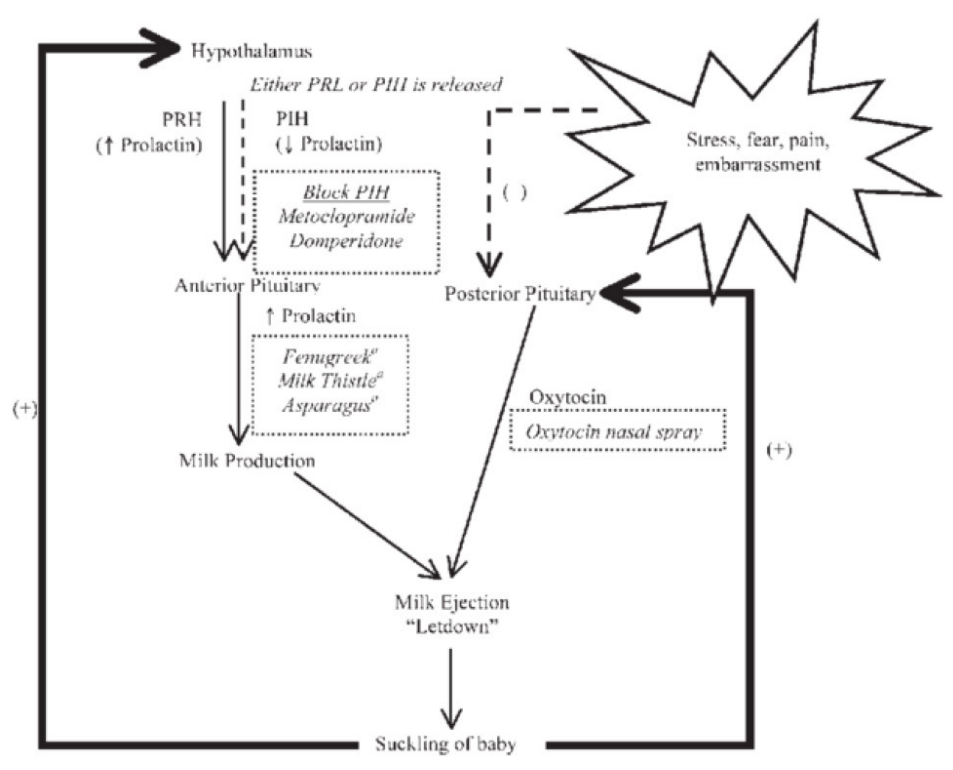

Figure 3. Physiologic of Lactation and Possibility of Work Action. ${ }^{11}$ 
(E2) that could trigger the prolactin gene expression through independent pathways and an unknown pathway in the pituitary lactotropic cells as a producer of the prolactin hormone. ${ }^{11}$

The first pathway through the intracellular receptor E2 (E2R) ultimately increases prolactin gene expression and increases breastmilk secretion (Figure 4). This effect is mediated by the triggering pathway of the a-isoform of the estrogen receptor membrane $(\mathrm{mE} 2 \mathrm{R})$. The second pathway is interfering with dopamine D2R receptors, stimulating the hormone prolactin production, proliferation of lactotropic cells in the pituitary by increasing the cAMP pathway in PKA phosphorylase, which triggers expression of the prolactin gene. Therefore, the prolactin hormone's secretion into the vasculature increases and affects the mammary alveoli cells, containing lots of prolactin receptors and can ultimately increase milk production. The E2-like action may induce PRL expression in anterior pituitary lactotrophic cells and milk production in mammae by indeterminate pathways. In lactotrophic cells, upregulation of PRL gene expression and secretion occurs directly by E2R and indirectly bymE2R inducing $\mathrm{D} 2 \mathrm{R}$ inhibition. ${ }^{1,10}$

Previous research by Setyaningsih et al. supported this hypothesis. The paper explained that the Katuk plant could increase breastmilk production, presumably based on the hormonal effect of chemical sterols, which are estrogenic. Katuk leaves contain steroids and polyphenols, which can increase prolactin levels. Also, the Katuk plant has abundant other micronutrients. A $100 \mathrm{~g}$ of katuk

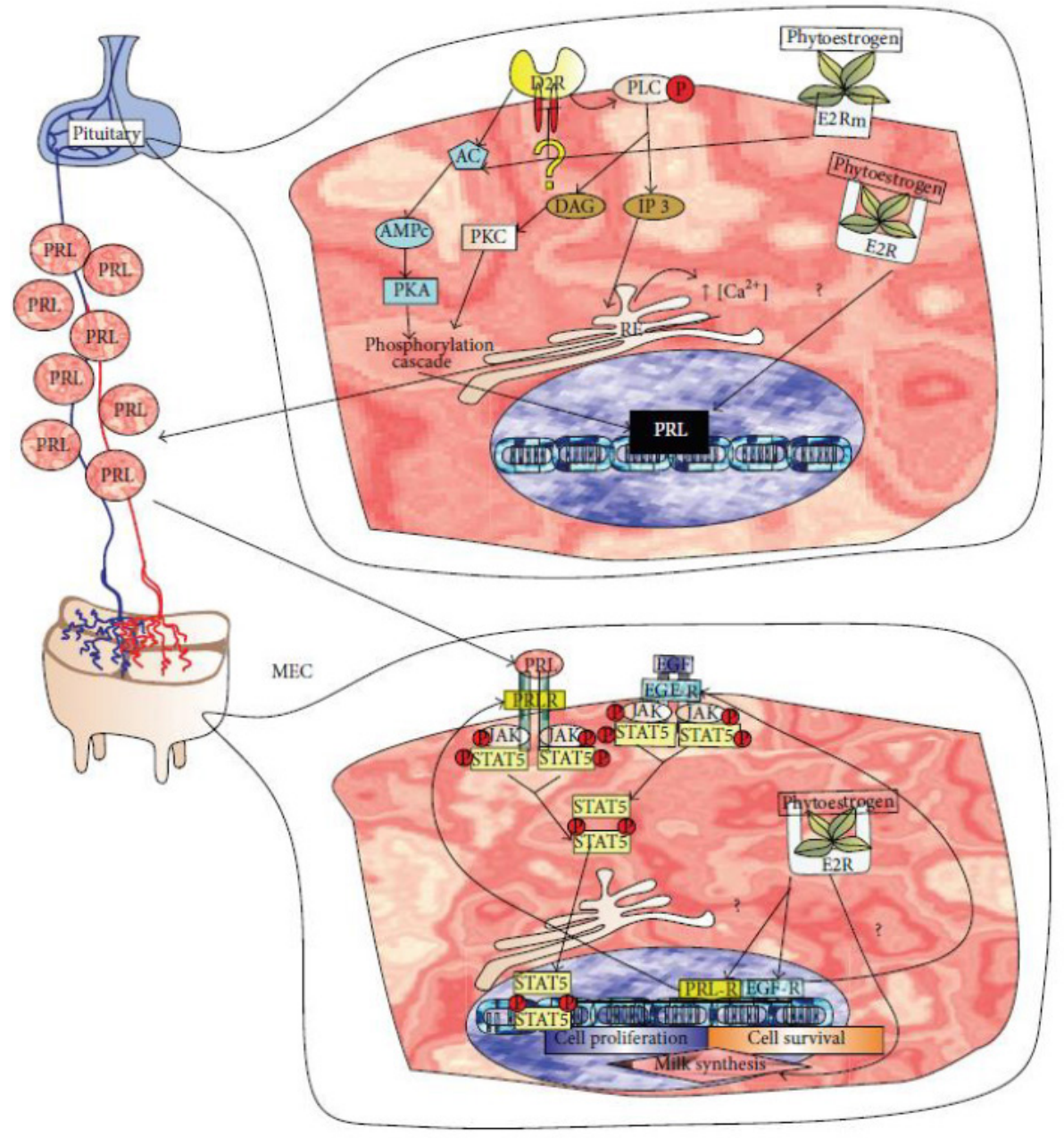

Figure 4. Proposed Galactogogue Mechanism of Action of Phytoestrogen Molecules in Anterior Pituitary and Mammary gland. ${ }^{1}$ leaves contain $204 \mathrm{mg}$ of calcium and 200 $\mathrm{mg}$ of vitamin $\mathrm{C}$, in addition to fiber and other nutrients such as protein, carotene, vitamins $\mathrm{A}$ and $\mathrm{B}$ and clhoropyll. ${ }^{13}$

Prolactin hormone levels in breastfeeding mothers fall by around 50 percent during the first week after giving birth. The hormone prolactin's basal level in nursing mothers averaged $90 \mathrm{ng} / \mathrm{ml}$ at ten days after delivery. This level would slowly decrease over the 180 postpartum days to $44.3 \mathrm{ng} / \mathrm{ml}$. Thus, to maintain breast milk production, it is necessary to have high levels of Prolactin. ${ }^{14}$ It is proven that in the case of mothers with premature babies with gestational age $\leq 36$ weeks, there is no milk production, and it turns out that the basal prolactin hormone level is $45 \mathrm{ng} / \mathrm{ml}$. Whereas for mothers who deliver term babies and can express breast milk, it turns out that the hormone prolactin level reaches $90-110 \mathrm{ng} / \mathrm{ml}$. Thus, giving galactagogue to mothers who give preterm birth is very useful to induce an increase in prolactin hormone levels up to the equivalent of mothers who give birth at term to increase milk production. ${ }^{6,14}$ This is in line with Mortel et al. that showed galactagogue herbs can increase serum levels of the hormone prolactin, oxytocin, breast milk volume, infant weight, and improve breast milk composition. ${ }^{15}$ Recent study by Indryani et al. also shows that katuk leaves supplementation in biscuit form also significantly increases prolactin level. ${ }^{14}$ These several findings proved that katuk leaf provided a beneficial effect on milk production and increase prolactin level.

\section{CONCLUSION}

Katuk (Sauropus androgunus (L) Merr) leaf is a medicinal plant that contains a relatively high amount of antioxidants. This plant also has a breastfeeding inducing effect due to its high content of Papaverine content. The previous study had shown that Katuk leaf supplementation proved beneficial to breastfeeding mothers by increasing prolactin levels, the essential hormone for breastfeeding. Further research is needed to determine the exact pathway and working mechanism of Katuk leaf in the breastfeeding physiological pathway. 


\section{CONFLICT OF INTEREST}

All authors declare that there is no conflict of interest.

\section{FUNDING}

This study does not involve any thirdparty support or funding.

\section{AUTHORS CONTRIBUTION}

All authors have contributed equally during all the study phases, including conducting the study, drafting and revising the manuscript, giving final approval, and agreeing to be accountable.

\section{REFERENCE}

1. Penagos Tabares F, Bedoya Jaramillo JV, RuizCortés ZT. Pharmacological overview of galactogogues. Vet Med Int. 2014;2014:602894.

2. Andarwulan N, Batari R, Sandrasari DA, Bolling B, Wijaya H. Flavonoid content and antioxidant activity of vegetables from Indonesia. Food Chem. 2010;121(4):1231-1235.
3. Andarwulan N, Batari R, Sandrasari DA, Bolling $\mathrm{B}$, Wijaya $\mathrm{H}$. Flavonoid content and antioxidant activity of vegetables from Indonesia. Food Chem. 2010;121(4):1231-1235.

4. Zhang BD, Cheng JX, Zhang CF, Bai YD, Liu WY, Li W, et al. Sauropus androgynus L. Merr.-A phytochemical, pharmacological and toxicological review. J Ethnopharmacol. 2020;257:112778.

5. Christi VEI. Study of pharmacognostical, anti-inflammatory and antioxidant activity of "Saropus androgynus" plant. Int J Adv Pharm Res. 2014;5(3);198-207.

6. Damis E, Gucciardo L, Berrefas L, Goyens P. Breastfeeding: from physiology to practical aspects. Rev Med Brux. 2012;33(4):318-327.

7. Hartmann PE, Owens RA, Cox DB, Kent JC. Breast development and the control of milk synthesis. Food and Nutrition Bulletin. 1996;17(4):292-302.

8. Glasier A, McNeilly AS, Howie PW. The prolactin response to suckling. Clin Endocrinol (Oxf). 1984;21(2):109-116.

9. Freeman ME, Kanyicska B, Lerant A, Nagy G. Prolactin: structure, function, and regulation of secretion. Physiol Rev. 2000;80(4):1523-1631.

10. Ramsay DT, Kent JC, Owens RA, Hartmann PE. Ultrasound imaging of milk ejection in the breast of lactating women. Pediatrics. 2004;113(2):361-367.
11. Forinash AB, Yancey AM, Barnes KN, Myles TD. The use of galactogogues in the breastfeeding mother. Ann Pharmacother. 2012;46(10):13921404.

12. Soka S, Alam H, Boenjamin N, Agustina TW, Suhartono MT. Effect of Sauropus androgynus leaf extracts on the expression of prolactin and oxytocin genes in lactating BALB/C mice. J Nutrigenet Nutrigenomics. 2010;3(1):31-36.

13. Setyaningsih DNHL, Agustina T. Acceptability and Nutritional Content of Katuk Leaf Plain Bread for Breasfeeding Mothers. Jurnal Kompetensi Teknik Universitas Negeri Semarang. 2014;6:53-58.

14. Indrayani D, Shahib MN, Husin F. The Effect of Katuk (Sauropus androgunus (L) Merr) Leaf Biscuit on Increasing Prolactine Levels of Breastfeeding Mother. Jurnal Kesehatan Masyarakat. 2020;16(1):1-7.

15. Mortel M, Mehta SD. Systematic review of the efficacy of herbal galactogogues. J Hum Lact. 2013;29(2):154-162.

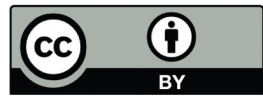

This work is licensed under a Creative Commons Attribution 